\title{
Genotype-Dependent Differences in Sleep, Vigilance, and Response to Stimulants
}

\author{
Hans-Peter Landolt*
}

Institute of Pharmacology \& Toxicology, University of Zürich, Zürich, Switzerland and Zürich Center for Integrative Human Physiology (ZIHP), University of Zürich, Zürich, Switzerland

\begin{abstract}
To better understand the neurobiology of sleep disorders, detailed understanding of circadian and homeostatic sleep-wake regulation in healthy volunteers is mandatory. Sleep physiology and the repercussions of experimentallyinduced sleep deprivation on sleep and waking electroencephalogram (EEG), vigilance and subjective state are highly variable, even in healthy individuals. Accumulating evidence suggests that many aspects of normal sleep-wake regulation are at least in part genetically controlled. Current heritability estimates of sleep phenotypes vary between approximately 20-40\% for habitual sleep duration, to over $90 \%$ for the spectral characteristics of the EEG in nonREM sleep. The molecular mechanisms underlying the trait-like, inter-individual variation are virtually unknown, and the human genetics of normal sleep is only at the beginning of being explored. The first studies identified distinct polymorphisms in genes contributing to the endogenous circadian clock and neurochemical systems previously implicated in sleep-wake regulation, to modulate sleep architecture and sleep EEG, vulnerability to sleep loss, and subjective and objective effects of caffeine on sleep. These insights are reviewed here. They disclose molecular mechanisms contributing to normal sleep-wake regulation in humans, and have potentially important implications for the neurobiology of sleep-wake disorders and their pharmacological treatment.
\end{abstract}

Key Words: Candidate gene, genome-wide association, pharmacogenetics, PER3, adenosine, serotonin, dopamine, modafinil.

\section{INTRODUCTION}

Each day of human life is characterized by alternating periods of sleep and wakefulness. An endogenous oscillator with a period of approximately one day (from lat. circa diem $=$ about a day) and an hourglass mechanism keeping track of sleep and wakefulness ("sleep homeostasis") interact to regulate timing and duration of sleep, sleep structure, rhythmic oscillations in the electroencephalogram (EEG), as well as predictable variation in cognitive functions and subjective state [1-7]. The molecular bases of normal human sleep and its physiological regulation are virtually unknown. It has recently been appreciated, however, that many aspects of sleep and sleep-wake regulation are highly variable among individuals, yet highly stable within individuals. Uncovering genetic factors contributing to these trait-like individual differences constitute one of the most promising avenues to foster our understanding of the neurobiology of sleep in health and disease. This review will discuss our current knowledge of genetic variation that contributes to inter-individual differences in sleep, the sleep EEG, and the response to sleep deprivation and stimulants primarily in healthy individuals. Accumulation of such insights into the molecular bases of normal sleep-wake regulation is likely to lead to improved and more personalized treatments of impaired sleep and vigilance associated with sleep and medical disorders, as well as modern life style.

\footnotetext{
*Address correspondence to this author at the Institute of Pharmacology \& Toxicology, University of Zürich, Winterthurerstrasse 190, 8057 Zürich, Switzerland; Tel: + 41 - 44 - 63559 53; Fax: + 41 - 44 - 63557 07;

E-mail: landolt@pharma.uzh.ch
}

\section{SLEEP AND SLEEP-RELATED PHENOTYPES}

Large inter-individual differences are observed in many sleep and sleep-related variables including sleep timing, sleep duration, sleep structure, and preferred time of day for completion of distinct cognitive tasks. Age and sex may explain a large proportion of this inter-individual variance [4]. Nevertheless, each of these phenotypes is also under genetic control. Consistent with this notion, a moderate to high degree of heritability, i.e., the percentage of variance explained by overall genetic effects, has been demonstrated for several sleep and sleep-related variables. Twin studies are the classical approach to estimate and quantify the relative impact of genes compared with influences of the environment.

\section{Sleep Timing}

The timing of sleep, as well as many other circadian rhythms in physiology, behavior and neurological functions are strongly determined by a self-sustained circadian oscillator. This oscillator consists at the molecular level of a network of inter-locked transcriptional/translational feedback loops, which involve several clock-related genes including the transcription regulators CLOCK, BMAL1, PER1-3, CRY1-2, and TIM [8].

Nocturnal sleep time, but also peaks and troughs of alertness, are highly variable among healthy individuals. Selfrating scales such as the Horne-Östberg Chronotype Questionnaire [9] and the Diurnal Type Scale [10] show normal distribution of diurnal preference along an "eveningness morningness" axis [11]. Such a distribution in a quantitative 
trait indicates the contribution of additive, small effects of many genes in combination with the environment. A recent study in a large number of monozygotic (MZ) and dizygotic (DZ) twins revealed that diurnal preference has a significant genetic component, which underlies roughly $50 \%$ of the inter-individual variation [12].

\section{Sleep Duration}

Also sleep length shows large variation among adult individuals. Systematic investigations of the relative contribution of circadian and homeostatic factors determining interindividual differences in sleep duration revealed that the biological night is shorter in short sleepers than in long sleepers [13]. Whether this difference is cause or consequence of the different sleep duration and associated changes such as light exposure, has not been established. While the dynamics of sleep homeostasis appear to be similar in both groups, sleep and waking EEG analyses suggest that short sleepers tolerate higher sleep pressure than long sleepers [14, 15].

An internet survey about self-rated caffeine sensitivity and sleep was recently conducted among $20^{\prime} 343$ University students [16]. A total number of 2'308 men and 2'021 women responded (response rate: $21 \%$ ). Diurnal preference alike, habitual sleep duration (average between workdays and weekends) shows a perfect normal distribution (Fig. 1), consistent with the influence of multiple, low-penetrance polymorphisms. Accordingly, several older studies reported for sleep duration moderate heritability estimates of 30-40\% [17-19].

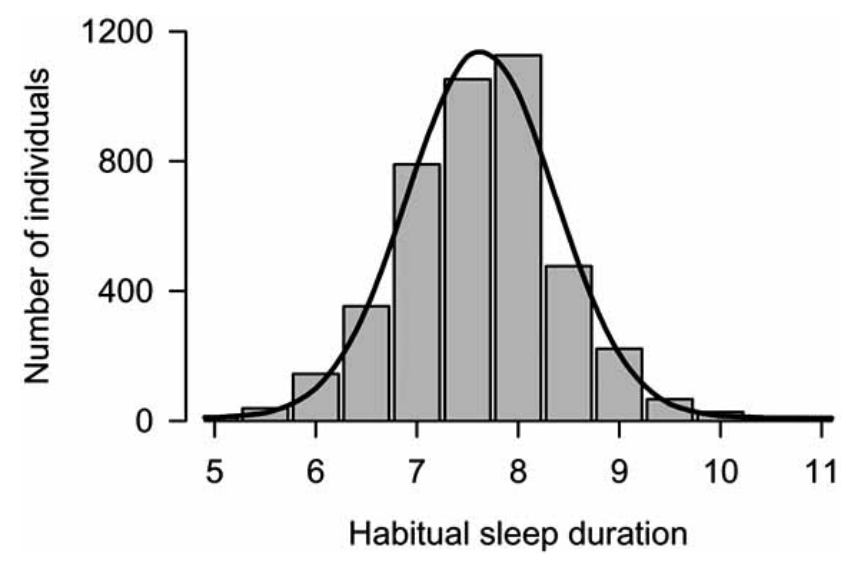

Fig. (1). Large variation and normal distribution in self-rated sleep duration (average over workdays and weekends) among 4'329 respondents to a brief internet questionnaire addressed to University students (age: $23.6 \pm 3.6$ years).

\section{Sleep Architecture}

Distinct oscillations in the EEG, together with information derived from the electrooculogram (EOG) and the electromyogram (EMG) serve to discriminate among non-rapideye-movement (nonREM) sleep, rapid-eye-movement (REM) sleep, and wakefulness [20]. Nocturnal sleep in healthy humans is typically initiated with stage 1 . Reflecting increasing sleep depth, nonREM sleep is further subdivided into the stages 2 to 4. A normal sleep episode consists of four or more consecutive nonREM/REM sleep cycles with a period length of roughly 80-120 minutes.

Many variables characterizing sleep architecture demonstrate large variation among individuals and high stability within individuals [21-24]. This observation suggests the presence of trait-like, inter-individual differences in sleep physiology. Indeed, twin studies show striking similarity and concordance in visually defined sleep variables in MZ twins, yet not in DZ twins. Already the first polysomnographic sleep studies in MZ twins revealed almost complete concordance in the temporal sequence of sleep stages [25]. Subsequent work showed that in particular those variables, which most reliably reflect sleep need are under tight genetic control. They include total sleep time, duration of nonREM sleep stages, especially slow wave sleep (i.e., combined stages $3 \& 4$ ), and density of rapid eye movements in REM sleep [26-28]. Linkowski estimated that heritability of markers of sleep homeostasis is up to $90 \%$ (REM density) [28]. Nevertheless, visual sleep state scoring relies on arbitrarily defined criteria [20] and can reveal only limited information about sleep physiology.

\section{Sleep and Waking EEG}

To obtain more detailed insights, quantitative analyses of the EEG signal recorded during sleep and wakefulness have to be performed. A powerful approach to quantify amplitude and prevalence of EEG oscillations with distinct frequencies is power spectral analysis based on Fast-Fourier Transform (FFT) $[22,29,30]$. NonREM sleep stage 1 is recognized by a pattern of theta $(\sim 5-9 \mathrm{~Hz})$ activity. The EEG in stage 2 is characterized by the occurrence of phasic events representing sleep spindles $(\sim 11-15 \mathrm{~Hz}$, sigma frequency range) and $\mathrm{K}$-complexes. In slow wave sleep, high-amplitude, slow waves in the delta frequency range $(<4 \mathrm{~Hz})$ are most prevalent. REM sleep is identified by low-amplitude EEG activity similar to stage 1. Finally, wakefulness with closed eyes is characterized in many individuals by regular alpha $(\sim 8$ $10 \mathrm{~Hz}$ ) activity. The distinct EEG characteristics of nonREM sleep, REM sleep, and wakefulness are faithfully reflected in the EEG power spectrum of these vigilance states (Fig. 2).

Recent studies strongly suggest that especially the sleep EEG, but also the waking EEG, are highly heritable traits in humans. All-night sleep EEG spectra derived from multiple recordings in healthy individuals show large inter-individual variation and high intra-individual stability $[22,23]$. For example, Buckelmüller et al. [23] recorded in 8 young men 2 pairs of baseline nights separated by 4 weeks. While the spectra in nonREM sleep differed largely among the individuals, the absolute power values and the shape of each subject's spectra were impressively constant across all nights (for representative example, see Fig. 3A). Hierarchical cluster analysis of Euclidean distances based on spectral values as feature vectors demonstrated that all 4 nights of each individual segregated into the same single cluster (Fig. 3B). Similar results were obtained in REM sleep [23], and by other researchers in men and women of older age [22]. These data strongly suggest that the sleep EEG contains systematic and stable inter-individual differences, which are at least in part genetically determined. This conclusion is supported by 
two recent studies comparing for the first time the spectral composition of the sleep EEG between MZ and DZ twin pairs. In nonREM sleep, the within-pair concordance in spectral power in the $2-13 \mathrm{~Hz}$ range is significantly higher in

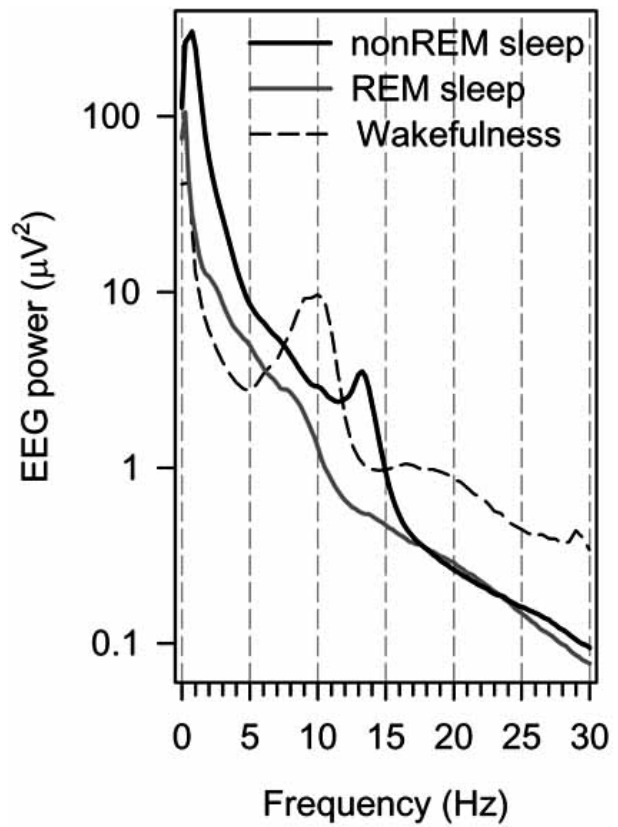

Fig. (2). Spectral characteristics of the EEG (derivation C3-A2) in nonREM sleep, REM sleep and rested wakefulness. NonREM sleep (combined stages 1-4) and REM sleep: All-night power spectra of an 8-hour baseline night (00:00 - 08:00) in 22 healthy men (age: $23.4 \pm 0.5$ years). Frequency resolution: $0.25 \mathrm{~Hz}$. Wakefulness: Average over two, 3-min EEG recordings with closed eyes conducted at 08:15 and 11:00 in the morning following the baseline night. Frequency resolution: $0.5 \mathrm{~Hz}$.

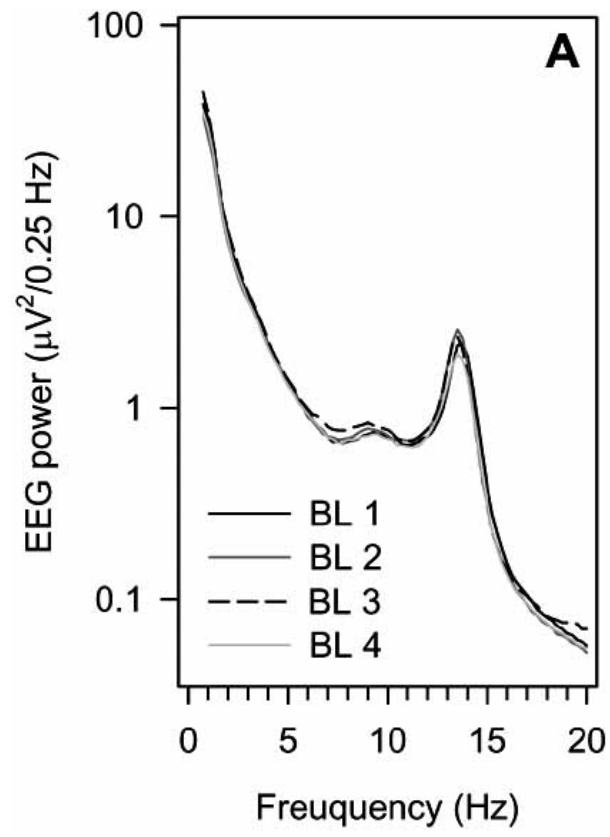

MZ twins than in DZ twins [31]. Especially alpha/sigma frequencies appear to reflect particularly strong genetic influences. Indeed, heritability in this frequency range may be as high as $96 \%$ [32].

Whereas the first quantitative sleep EEG studies in twins are published only now, it has long been reported that the waking EEG has much higher resemblance between MZ twins than between DZ twins and unrelated persons [33-35]. Subsequent findings confirmed that genetic factors underlie pronounced inter-individual differences and high intraindividual test-retest correlation in spontaneous waking EEG activity [36, 37]. Van Beijsterveldt and co-workers estimated that the heritability of delta, theta, alpha and beta $(>12 \mathrm{~Hz})$ frequencies in the waking EEG is over $75 \%$ [37].

\section{HOMEOSTATIC SLEEP-WAKE REGULATION}

During wakefulness, sleep pressure accumulates, and during sleep, sleep pressure dissipates. Sleep homeostasis refers to the general principle of sleep-wake regulation that an accumulated sleep debt is highly predictably compensated [3, 38, 39]. In humans as well as animals, sleep after total or partial sleep deprivation - or rest deprivation in species in which sleep and waking cannot be unambiguously defined based on the EEG criteria - occurs with reduced latency, and is prolonged and more intense than baseline sleep. It is widely accepted that EEG delta/theta and spindle frequency activity (SFA) in nonREM sleep serve as physiological markers of sleep homeostasis in humans. The duration of slow wave sleep and initial low-frequency activity rise as a function of time awake, while SFA is typically reduced after sleep deprivation [29, 40-42].

An EEG correlate of sleep homeostasis can also be tracked during wakefulness. Power in the theta/low-alpha

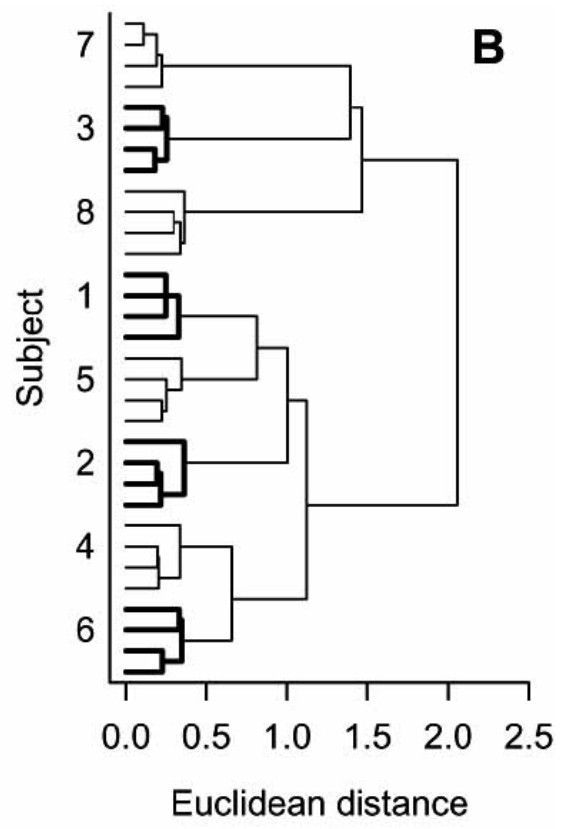

Fig. (3). Trait-like individual differences in nonREM sleep EEG in healthy men (age: $24.1 \pm 0.6$ years). (A) High intra-individual stability in nonREM sleep EEG power spectrum $(0.75-20 \mathrm{~Hz}$, derivation C3-A2). Two pairs of 2 consecutive baseline nights (23:00 - 07:00) separated by 4 weeks (BL $1 \&$ BL 2 and BL 3 \& BL 4). (B) Hierarchical cluster analysis allows separation of 8 individuals only based on Euclidean distances among feature vectors derived from EEG power spectra $(0.75-20 \mathrm{~Hz}$, frequency resolution: $0.25 \mathrm{~Hz})$. All 4 nights of each individual segregated in the same cluster. Data adapted and replotted from Buckelmüller et al. [23]. 
band of the waking EEG increases during prolonged time awake [41, 43-45]. The time constant of this increase is similar to that of the wake-dependent increase of low-frequency activity in nonREM sleep $[44,45]$. This finding suggests that the enhancement of delta activity in recovery sleep, and the rise rate of theta activity during waking are closely related. Both changes are larger over anterior than over posterior cortical areas [46]. In fact, the spatial distribution of EEG oscillations in nonREM sleep is highly stable across multiple recordings within the same individual. Thus, sleep EEG topography was proposed to reflect an individual "fingerprint", which is genetically determined [32, 47, 48].

Sleep deprivation not only affects sleep and waking EEG, but also alertness and performance on neurobehavioral and cognitive tasks. There exists, however, large inter-individual variation in performance decline during prolonged waking [49-51]. The differences are substantial and stable, even when sleep duration before sleep deprivation is experimentally varied (sleep restriction $v s$. sleep extension). The differences between vulnerable and resistant subjects do not reflect inter-individual differences in sleep need. In addition, the changes on distinct tasks show no clear relationships. More specifically, performance after sleep deprivation is clearly impaired in certain subjects on one task, while the same subject can even improve on another task [51]. Similarly, the evolution of wakefulness-induced changes in EEG theta/alpha activity, subjective sleepiness, and neurobehavioral performance can widely dissociate $[49,50,52]$. Taken together, accumulating data suggest that the magnitude of performance impairment from sleep loss reflects trait-like individual vulnerability $[53,54]$, yet the underlying neurobiological mechanisms are currently unknown.

\section{HUMAN GENETICS OF NORMAL SLEEP-WAKE REGULATION}

The manifestation and regulation of sleep, the sleep and waking EEG, as well as sleep-related waking functions reflect different aspects of complex behaviors. Each of these aspects is likely to be under the control of multiple genes, which may interact, and are also influenced by the environment. Considerable knowledge accumulated over the past years about the roles of distinct genes for sleep in model systems and patients with sleep disorders (e.g., [55-57]). By contrast, very little is known about the genes that contribute to the trait-like, individual "sleep-phenotypes". This lack of knowledge may reflect the fact that precise quantification of these phenotypes in healthy individuals requires controlled, long-lasting and cost-expensive experiments relying on hightech methodology, as well as time-consuming data analyses.

Three main techniques for the genetic dissection of normal human sleep are currently available. The first is to examine the impact of candidate genes, for which evidence exists that they are implicated in sleep and sleep-wake regulation. With this method, individuals with distinct genotypes of known genetic polymorphisms are prospectively studied in the sleep laboratory. A limitation of this approach is that it precludes "sleep gene discovery". By contrast, genome-wide association studies may lead to the identification of novel "sleep genes". The weaknesses and strengths of these strategies were previously discussed in detail [58, 59]. Finally, a virtually unexplored, yet powerful approach to obtain insights into the molecular mechanisms of sleep-wake regulation is sleep pharmacogenetics.

In the following paragraphs, I shall summarize current concepts primarily derived from preclinical studies of neuroanatomy and neurochemistry of sleep-wake regulation, followed by an overview of the present state of knowledge of genes that influence normal human sleep. As a general remark, most current evidence suggesting a direct association between genetic variation in distinct "clock" genes and/or "sleep" genes and the physiological mechanisms underlying sleep-wake regulation may still be controversial and awaits confirmation.

\section{NEUROANATOMY/NEUROCHEMISTRY OF SLEEP- WAKE REGULATION}

It is well established that the "master" clock driving circadian rhythms is located in mammals in the suprachiasmatic nuclei $(\mathrm{SCN})$ of the hypothalamus. By contrast, the neuroanatomical and neurochemical bases underlying sleep homeostasis are poorly understood. In vivo and in vitro electrophysiological studies revealed that the EEG characteristics of nonREM sleep, REM sleep, and wakefulness reflect the firing patterns of thalamo-cortico-thalamic and intra-cortical networks [60]. The firing of these cells is modulated by distinct neural systems originating in basal forebrain, hypothalamus and brain stem, which are thought today to importantly contribute to sleep-wake regulation [61-63].

\section{Neural Systems Promoting sleep}

Prominent roles for basal forebrain and rostral hypothalamic structures in generating and maintaining sleep have long been suggested from lesion studies in animals and clinical observations in humans [61]. More recent insights support this notion. For example, microdialysis experiments in cats and rats suggest that the extracellular adenosine concentration in basal forebrain is modulated by the sleep-wake cycle $[64,65]$. Binding of adenosine to inhibitory $A_{1}$ receptors reduces excitatory neurotransmission and may contribute to sleep homeostasis [66]. However, a causal relationship between site-specific changes in extracellular adenosine and sleep homeostasis is controversial (see [67] for discussion). In humans, positron emission tomography (PET) indicated that sleep deprivation modulates adenosine $\mathrm{A}_{1}$ receptor binding throughout cortical and subcortical brain regions, rather than in region-specific manner [68].

Another possibility for adenosine to promote sleep is via disinhibition of adenosine $\mathrm{A}_{2 \mathrm{~A}}$ receptor-expressing neurons in basal forebrain and ventro-lateral preoptic (VLPO) area of the hypothalamus. Electrophysiological studies in freely moving rats have shown that the discharge rate of VLPO neurons is more than doubled during sleep when compared to wakefulness $[69,70]$. Moreover, expression of the immediate early gene, Fos, in the VLPO is closely related to the amount of sleep obtained by the animal before FOS protein quantification [71]. In accordance with these animal studies, a relative increase in regional glucose metabolic rate in nonREM sleep compared to wakefulness was also found in basal forebrain/preoptic hypothalamus in humans [72]. The VLPO neurons form a dense cluster and a more diffuse extended 
part containing the inhibitory neuromodulators galanin and $\gamma$-amino-butyric acid (GABA) [73-75]. Axons from the VLPO innervate cell bodies and dendrites of the noradrenergic locus coeruleus (LC), the serotonergic dorsal raphe nucleus (DRN), the histaminergic tuberomammillary nucleus (TMN), and also terminate within cholinergic cell groups of basal forebrain and the latero-dorsal/pedunculo-pontine tegmental (LDT/PPT) areas of the brain stem [75-78]. On the other hand, the VLPO receives afferents from each of the major monoaminergic systems [79]. These reciprocal connections suggest that VLPO activity is suppressed by the same arousal systems (see below) that it inhibits during sleep.

Electrophysiological recordings in rat brain slices demonstrate the existence of two distinct types - Type-1 and Type-2 - of sleep-active VLPO neurons [80, 81]. While stimulation of post-synaptic $\mathrm{A}_{1}$ receptors inhibits both types of cells, pharmacological blockade of these receptors produces a reversible increase in spontaneous firing in Type- 2 cells, which is further enhanced when adenosine is applied [81]. This effect reflects activation of $\mathrm{A}_{2 \mathrm{~A}}$ receptors, because a selective $A_{2 A}$ receptor agonist excites Type-2, but not Type-1 neurons. It is possible that adenosine disinhibits both subtypes of sleep-active cells through pre-synaptic reduction of GABA release, and actively excites Type- 2 neurons through post-synaptic activation of $\mathrm{A}_{2 \mathrm{~A}}$ receptors.

In recovery sleep after 12-14 hours sleep deprivation, VLPO neurons display an even larger sleep-related increase in discharge rate than in baseline sleep [70]. Enhanced FOS immunoreactivity and cell firing in VLPO, however, are not increased in waking, but only after the animals enter sleep. This finding suggests that VLPO activity promotes sleep onset and/or consolidation, rather than underlies increased sleepiness and impaired waking functions associated with inadequate sleep [82]. The differences between Type-1 and Type-2 neurons may indicate that the latter are involved in sleep initiation, whereas the former contribute to sleep consolidation [81]. They are only activated when released from inhibition by monoaminergic and cholinergic arousal systems.

\section{Neural Systems Promoting Wakefulness}

Classical studies have shown that the brainstem reticular formation modulates cortical activation via a dorsal pathway through the thalamus, as well as a ventral, extra-thalamic pathway through the posterior hypothalamus and basal forebrain [83]. The main thalamic projection originates in LDT/PPT. Cell groups originating in LC, DRN, and TMN contribute to the extra-thalamic branch of the ascending arousal system. It is joined in posterior lateral hypothalamus by axons from orexin- (also known as hypocretin) and melanin-concentrating hormone-containing neurons, as well as in basal forebrain from acetylcholine-containing cells.

Cholinergic LDT/PPT neurons fire rapidly in wakefulness and REM sleep, whereas few cells are active in nonREM sleep. During this state, reduced cholingergic inhibition of GABA-ergic thalamic reticular neurons leads to hyperpolarization of thalamo-cortical cells resulting in the occurrence of delta waves and sleep spindles [60].

Clinical observations in neurologic patients and lesion studies in animals indicate that the noradrenergic system stimulates and maintains cortical activation and modulates the quality of arousal $[61,84]$. The activity of the LC is high during wakefulness and low during sleep [85]. Destruction of nerve fibers originating in $\mathrm{LC}$ in rats with the neurotoxin DSP-4 reduces low-range $(<1 \mathrm{~Hz})$ delta activity in nonREM sleep after both spontaneous and enforced wakefulness [86]. These findings support the hypothesis that noradrenaline release during wakefulness is causally related to the intensity of subsequent sleep.

Clinical symptoms of disorders such as Parkinson's Disease, which is associated with reduced dopaminergic neurotransmission, often include disturbed sleep and vigilance [87]. Dopaminergic neurons of ventral tegmental area and substantia nigra are involved in behavioral arousal $[61,88]$. Moreover, amphetamine-like stimulants including methamphetamine and methylphenidate increase wakefulness by blocking catecholamine (i.e., adrenaline, noradrenaline and dopamine) re-uptake from the synaptic cleft and/or stimulating catecholamine release [89]. Genetically modified mice, in which the dopamine transporter (Dat) gene was deleted, exhibit reduced nonREM sleep and prolonged wakefulness when compared to wildtype littermates [90]. In addition, Dat knock-out mice are unresponsive to the normally robust wake-promoting action of catecholaminergic agents, yet hypersensitive to the adenosine receptor antagonist caffeine [90].

Though it has long been suggested that serotonin (5-hydroxy-tryptamine, 5-HT) is critical for sleep-wake mechanisms [91], the specific roles for this neurotransmitter remain uncertain [61, 92]. The serotonergic neurons of the DRN exhibit the highest discharge rate in waking, show diminished activity in nonREM sleep, and are virtually silent shortly before and during REM sleep [93, 94]. This firing pattern is mimicked by changes in the extracellular 5-HT concentration across sleep-wake alternations in rats and cats $[95,96]$, elevated 5-HT levels in the rat hippocampus during sleep deprivation [95], and ultradian variation of ventricular 5-HT concentration across nonREM/REM sleep cycles in humans [97]. These and other data may support the notion that serotonergic neurotransmission stimulates wakefulness and is partially (in nonREM sleep) or completely (in REM sleep) turned-off during sleep. Electrophysiological studies show that 5-HT inhibits or excites distinct VLPO cells in vitro $[74,81]$. More specifically, not only adenosine, but also 5-HT excites type-2 cells in VLPO [81].

Taken together, while other neurotransmitter/neuromodulator systems are certainly also involved (e.g., histamine, orexin, GABA, glutamate, acetylcholine, neuropeptides), adenosinergic, catecholaminergic and serotonergic influences contribute to sleep-wake regulation.

\section{CANDIDATE GENE APPROACH}

\section{Circadian Locomotor Output Cycles Kaput (CLOCK) Gene}

The effect of a single nucleotide polymorphism (SNP) in the 3'-untranslated region (UTR) of the human CLOCK gene on diurnal preference as assessed with the Horne-Östberg questionnaire was first studied in middle-aged adults. Polymorphisms in this region affect stability and half-life of messenger RNA [98], and possibly alter the protein level that is 
finally translated. Katzenberg et al. reported that homozygous carriers of the $3111 \mathrm{C}$ allele have increased evening preference for mental activities and sleep, with delays ranging from 10 to 44 minutes when compared to individuals carrying the $3111 \mathrm{~T}$ allele [99]. A similar association was found in a Japanese population [11], but not confirmed in European and Brazilian samples [100, 101]. Sleep variables derived from nocturnal polysomnography did not differ between the genotypes [99]. Interestingly, clinical and restactivity data in patients with mood disorders indicate that individuals with the $3111 \mathrm{C}$ allele have increased occurrence of disturbed sleep both during mood episodes as well as in remission, higher motor activity levels in the evening, and a different response to lithium than patients homozygous for the T allele [102-104].

\section{Period (PER) Genes}

In mice, Perl and Per2 play important roles in the maintenance of circadian rhythmicity, whereas Per3 functions outside the core circadian clock work [105]. Screening for missense mutations or functional polymorphisms in promoter and 5'- and 3'-UTRs of the human PERl gene in volunteers with extreme diurnal preference and patients with delayed sleep phase syndrome (DSPS) remained unsuccessful [106]. Moreover, a synonymous A to $G$ substitution at nucleotide 2548 showed no association with eveningnessmorningness tendencies [107]. By contrast, the distribution of the $\mathrm{C}$ and $\mathrm{T}$ alleles of a silent polymorphism in exon 18 differed between extreme morning and evening types [106]. Specifically, the frequency of the $2434 \mathrm{C}$ allele was significantly higher in subjects with extreme morning preference than in subjects with extreme evening preference.

A missense mutation in the human PER2 gene provides today the most striking example of a direct link with changed circadian rhythms. Thus, familial advanced sleep phase syndrome (FASPS) is associated with altered amino acid sequences in PER2 and casein kinase I delta (CKI $\delta$ ) proteins [108, 109]. A transgenic mouse model expressing the human FASPS mutation demonstrated that $\mathrm{CKI} \delta$ can regulate circadian period through PER2 [110]. A C111G polymorphism located in the 5'-UTR of PER2 was also reported to modulate diurnal preference in healthy volunteers [111]. Computer simulation predicted that the $111 \mathrm{G}$ allele, which may be associated with morning preference, has different secondary RNA structure than the $111 \mathrm{C}$ allele. It is possible that the two transcripts are differently translated [111].

A variable-number-tandem-repeats (VNTR) polymorphism in the human PER3 gene may modulate multiple phenotypic variables related to sleep timing, sleep architecture and vulnerability to sleep loss. A 54-nucleotide sequence located in a coding region of this gene is either repeated in four or five units. This difference may alter the dynamics in PER3 protein phosphorylation. In European and Brazilian populations, the longer 5-repeat allele and the shorter 4repeat allele were associated with morning preference and evening preference, respectively $[112,113]$. Moreover, homozygous carriers of the long-repeat genotype showed increased slow wave sleep and delta activity in nonREM sleep, as well as higher theta/alpha activity in REM sleep and wakefulness than homozygous 4-repeat individuals [114]. The decline in cognitive performance during sleep depriva- tion was worse in the former than in the latter, in particular during late-night and early-morning hours and on tasks of executive functioning [115]. These data may indicate that the genetic variation in PER3 affects sleep homeostasis. They support the notion that there are complex, mutual interactions between sleep-wake regulatory processes, and suggest a contribution of PER3 to individual tolerance to shift work and jet-lag, which are highly prevalent in society.

\section{Adenosine Deaminase (ADA) Gene}

The adenosine-metabolizing enzyme, adenosine deaminase (ADA), plays an important role in regulating extracellular adenosine levels [116]. We recently found in humans that a functional variation in the $A D A$ gene has a profound impact on sleep and the sleep EEG (Fig. 4). More than 30 allelic variants of $A D A$ are currently listed in the Online Mendelian Inheritance in Man (OMIM) database. Most of these variants represent non-functional alleles, which give rise to severe combined immunodeficiency. The most frequent allele that is asymptomatic in heterozygous carriers is caused by a $\mathrm{G}$ to A transition at nucleotide 22 , leading to the substitution of asparagine for aspartic acid at codon 8 of the ADA protein [117]. The G/A genotype is found in roughly $10 \%$ of healthy Caucasians, whereas the homozygous A/A genotype occurs in less than $1 \%$ of the population [118]. Compared to individuals with the $\mathrm{G} / \mathrm{G}$ genotype, individuals with the $\mathrm{G} / \mathrm{A}$ genotype exhibit lower enzymatic activity in erythrocytes and leucocytes [119] and may be at elevated risk to develop

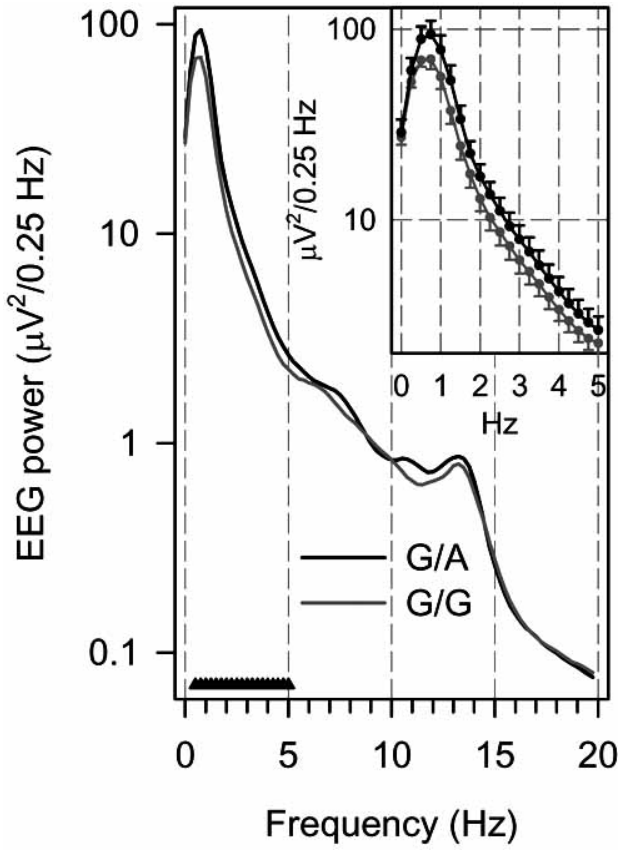

Fig. (4). The functional $22 \mathrm{G}>\mathrm{A}$ polymorphism of the adenosine demanise $(A D A)$ gene modulates nonREM sleep intensity in healthy individuals. All-night EEG power spectra in nonREM sleep (stages $1-4,0.25-20 \mathrm{~Hz}$, derivation C3-A2) in individually age- and sexmatched subjects with G/A (black lines, $\mathrm{n}=8$ ) and G/G genotypes (grey lines, $\mathrm{n}=8$ ). Mean absolute power values are plotted on a logarithmic scale. Triangles above the $\mathrm{x}$-axis indicate frequency bins $(0.75-5.0 \mathrm{~Hz})$ that differed significantly between the genotypes ( $p<0.05$, two-tailed paired t-tests). The frequency range between 0 and $5 \mathrm{~Hz}$ was expanded for better visualization (inset, error bars indicate + or - SEM). 
autism [120]. In accordance with the hypothesis that differences in extracellular adenosine levels affect markers of sleep homeostasis, baseline sleep in subjects with the G/A genotype was characterized by 30 minutes more slow wave sleep than in subjects with the G/G genotype [121]. Moreover, also the intensity of slow wave sleep as estimated from EEG delta activity was higher in the former than in the latter. While the differences associated with this polymorphism are similar in magnitude to the changes in sleep and the sleep EEG after one night without sleep, the consequences of sleep deprivation in individuals with distinct $A D A$ genotypes are currently unknown. Based on data in animals, it may be expected that G/A and G/G genotypes behave differently during prolonged wakefulness. More specifically, QTL analyses in inbred mouse strains revealed that a genomic region including Ada modifies the rate, at which nonREM sleep need accumulates during wakefulness [122].

It is tempting to speculate that pharmacological interference with ADA might provide a possible target to promote sleep and its intensity, for example in patients with insomnia. Indeed, blocking ADA by local application of (deoxy)coformycin in rats prolongs sleep and increases delta activity in nonREM sleep [123, 124]. However, elevated concentrations of adenosine and 2'-deoxyadenosine, another substrate of ADA, acting on adenosine receptors expressed on virtually all cells in the organism may lead to unwanted drug reactions.

\section{Other Possible Candidate Genes}

\section{Catechol-O-Methyltransferase (COMT) Gene}

Genetic evidence from patients with narcolepsy supports a role for noradrenergic/dopaminergic pathways in regulating sleep-wake functions. Distinct alleles and genotypes in the genes of monoamine oxidase type A (MAO-A) [125] but see [126] - and catechol-O-methyltransferase (COMT) [126] are thought to be associated with the clinical manifestation of narcolepsy. In particular, the human COMT gene contains a functional SNP that alters the amino acid sequence of the COMT protein at codon 158 from valine (Val) to methionine (Met) [127]. Individuals homozygous for the Val allele show more COMT protein in post-mortem brain tissue than individuals with two Met alleles [128]. Moreover, the $\mathrm{Val} / \mathrm{Val}$ genotype is associated with 3- to 4-fold higher COMT activity and presumably lower dopaminergic signaling in prefrontal cortex than the Met/Met genotype [128, 129]. The impact of this polymorphism on the severity of sleepiness as measured by multiple sleep latency tests (MSLT) supports the conclusion that sleep-wake symptoms in narcolepsy are associated with altered dopaminergic neurotransmission [126]. In addition, a more recent study found positive associations between narcolepsy and other genomic regions related to the monoaminergic system, including the genes of the dopamine $\mathrm{D}_{2}$ and serotonin $5-\mathrm{HT}_{2 \mathrm{~A}}$ receptors [130].

\section{Serotonin Transporter Gene (SLC6A4)}

Serotonin may contribute to the build-up of sleep pressure associated with wakefulness. Extracellular 5-HT is catabolized in glia cells and non-serotonergic neurons by MAOA to 5-hydroxy-indolacetic acid (5-HIAA). In addition,
5-HT is removed from the synapse by high-affinity serotonin transporters (5-HTT). The 5-HTT in brain is the principal site of action for many currently used antidepressants [131]. A functional VNTR polymorphism in the 5'-HTT promoter region of SLC6A4 has been consistently associated with psychiatric diagnoses and individual efficacy of antidepressant treatments. In vitro studies show that basal transcriptional activity of the long variant (L) allele is more than doubled when compared to the short $(\mathrm{S})$ variant allele [132]. Human individuals homozygous for the $\mathrm{L} / \mathrm{L}$ variant show higher 5-HTT messenger RNA levels in postmortem brain tissue than subjects carrying the $\mathrm{S}$ allele (L/S $+\mathrm{S} / \mathrm{S})$ [133]. It was speculated that reduced transcription associated with the $\mathrm{S}$ allele modulates serotonergic tone and 5-HT receptormediated neurotransmission [134]. Preliminary data indicate that the presence of the $\mathrm{S}$ allele affects subjective and objective measures of sleep in certain situations $[135,136]$. While the functional relationship between the genetic variation in SLC6A4 and sleep-wake regulation has not been studied in healthy individuals, it appears that homozygous depressed patients with the $\mathrm{L} / \mathrm{L}$ genotype respond more favorably to therapeutic sleep deprivation than carriers of the $\mathrm{S}$ allele [137].

Transgenic mice lacking functional 5-HTT and 5-HT $\mathrm{H}_{1 \mathrm{~A}}$ receptors show more REM sleep than wildtype littermates $[138,139]$. A recent PET study demonstrated that the insertion/deletion polymorphism in the promoter region of SCL6A4 affects $5-\mathrm{HT}_{1 \mathrm{~A}}$ receptor availability in humans [134]. More specifically, subjects with $\mathrm{L} / \mathrm{L}$ genotype have higher $5-\mathrm{HT}_{1 \mathrm{~A}}$ receptor binding in all brain regions than carriers of the $S$ allele. It is unknown whether this polymorphism also modulates availability of other 5-HT receptor subtypes. Notwithstanding, it may contribute to inter-individual differences in the efficacy of currently emerging hypnotics that improve sleep via a serotonergic mechanism of action $[140,141]$.

\section{Genome-Wide Association Studies}

Only one genome-wide association study of sleep-related phenotypes is currently available in humans [142]. Phenotypic and genetic analyses were conducted in 749 subjects and confirmed moderate heritability estimates for sleep duration $(17 \%)$ and habitual bedtime $(22 \%)$ as assessed by nonvalidated questionnaire, as well as subjective sleepiness as quantified by Epworth Sleepiness Scale (29 \%) [143]. Some genetic loci containing circadian clock-related genes including casein kinase II alpha-2 (CSNK2A2), CLOCK and prokineticin 2 (PROK2) were identified to modulate habitual bedtime and sleep duration, respectively. None of the investigated phenotypes, however, was associated with previously suspected candidate genes for sleep and sleep-wake regulation. Methodological issues such as the used questionnaire and limited gene-chip resolution may underlie the discrepancy. Association tests suggested that "novel genes" encoding neuropeptide $\mathrm{S}$ receptor 1 (NPSR1) and phosphodiesterase 4D (PDE4D) may influence habitual bedtime on workdays and self-rated sleepiness, respectively.

\section{Studies of Sleep Pharmacogenetics}

At least some effects of the neuromodulator adenosine on sleep appear to be mediated via the adenosine $\mathrm{A}_{2 \mathrm{~A}}$ receptor 
(see [144] for recent overview). In rats, selective $A_{2 A}$ receptor agonists such as CGS21680 administered to the subarachnoid space adjacent to basal forebrain and lateral preoptic area reliably induce nonREM sleep, while infusion of $\mathrm{A}_{1}$ receptor agonists produces weak and variable effects [145148]. Local application of CGS21680 also increases Fos expression in VLPO [147]. Activation of $\mathrm{A}_{2 \mathrm{~A}}$ receptors expressed in nucleus accumbens may underlie this finding. Moreover, Gallopin et al. demonstrated direct activation of sleep-promoting VLPO neurons via post-synaptic stimulation of $\mathrm{A}_{2 \mathrm{~A}}$ receptors [81]. Interestingly, CGS21680 and the adenosine receptor antagonist, caffeine, are ineffective in mice lacking functional $\mathrm{A}_{2 \mathrm{~A}}$ receptors $[149,150]$.

Caffeine is the most widely consumed stimulant in the World. To examine a role for $\mathrm{A}_{2 \mathrm{~A}}$ receptors in human sleepwake regulation, the interaction of caffeine with sleep deprivation was investigated in self-rated caffeine sensitive and insensitive individuals [16]. Alleles and genotypes of a synonymous $1083 \mathrm{~T}>\mathrm{C}$ polymorphism located in the coding region of the adenosine $\mathrm{A}_{2 \mathrm{~A}}$ receptor gene $(A D O R A 2 A)$ were differently distributed between two groups of subjects who either reported or not disturbed sleep after caffeine consumption in the evening. This polymorphism is linked to a $2592 \mathrm{C}>\mathrm{T}_{\text {ins }}$ polymorphism in the 3'-UTR of ADORA2A. The latter may modulate protein expression [151]. Supporting a role for $\mathrm{A}_{2 \mathrm{~A}}$ receptors in human sleep, caffeine increased higher-frequency $(>16 \mathrm{~Hz})$ EEG activity prominently in the $\mathrm{C} / \mathrm{C}$ genotype $(15.3 \pm 3.1 \%, \mathrm{n}=6)$, intermediately in the $\mathrm{C} / \mathrm{T}$ genotype $(6.9 \pm 3.0 \%, \mathrm{n}=10)$, and was ineffective in the T/T genotype $(-0.2 \pm 5.1 \%, \mathrm{n}=3)$ [16]. Elevated highfrequency activity in nonREM sleep reflects reduced sleep intensity and may be characteristic of patients with primary insomnia when compared to healthy good sleepers [152].

Both stimulant and anxiogenic properties of caffeine contribute to inter-individual differences in the subjective response to the drug [153]. The $1083 \mathrm{~T}>\mathrm{C}$ polymorphism of ADORA2A not only modulates effects on the sleep EEG, but is also associated with symptoms of anxiety after moderate caffeine intake $[151,154]$ and habitual caffeine consumption [155]. Sleep disruption and anxiety, respectively, appear to be distinctly favored by the $\mathrm{C}$ and $\mathrm{T}$ alleles of ADORA2A. To obtain more information about a possible adenosinergic mechanism linking sleep and mood regulation, the effects of caffeine on sleep and anxiety symptoms should be studied simultaneously in individuals with distinct ADORA2A genotypes.

The ADORA2A gene is located on human chromosome $22 q 11.2$, in close proximity to the gene encoding COMT. On the MSLT, female narcolepsy patients with high COMT activity (Val/Val allele carriers) fall asleep twice as fast as women narcoleptics with low COMT activity (Met/Met allele carriers) [126]. An opposite relationship is observed in men. Clinical data suggest that also the efficacy of the stimulant, modafinil, to control daytime sleepiness differs between women and men, and among COMT genotypes [156]. More specifically, the optimal daily dose of modafinil is $100 \mathrm{mg}$ lower in female than in male narcoleptics, yet higher in patients (men and women) with $\mathrm{Val} / \mathrm{Val}$ genotype than in patients with Met/Met genotype. Although the exact mode of action of modafinil is still controversial, the available data suggest that the drug stimulates wakefulness by promoting dopaminergic and (nor)adrenergic neurotransmission [157]. In healthy volunteers, the COMT genotype modulates the response of the prefrontal cortex to increased dopamine according to a inverted, U-shaped response curve [158]. It might, therefore, be expected that in healthy subjects modafinil would improve enhanced sleepiness after sleep loss more efficiently in the $\mathrm{Val} / \mathrm{Val}$ genotype than in the Met/Met genotype.

\section{CONCLUSION}

Sleep and sleep-wake regulation in humans represent highly variable phenotypes, which are increasingly appreciated to be under moderate to strong genetic control. The molecular mechanisms underlying this variation are virtually unknown. Recent genetic studies, however, revealed first insights and led to exciting progress in our understanding of the neurobiology of normal sleep and sleep-wake regulation. These new findings have potentially important implications for the neurobiology of sleep-wake disorders and their pharmacological treatment.

\section{ACKNOWLEDGMENTS}

I thank Prof. M. Tafti and Dr. C. Kopp for helpful suggestions. The author's research was supported by the Swiss National Science Foundation.
ABBREVIATIONS

\begin{tabular}{|c|c|c|}
\hline NonREM sleep & $=$ & Non-rapid-eye-movement sleep \\
\hline REM sleep & $=$ & Rapid-eye-movement sleep \\
\hline EEG & $=$ & Electroencephalogram \\
\hline EOG & $=$ & Electrooculogram \\
\hline EMG & $=$ & Electromyogram \\
\hline CLOCK & $=$ & $\begin{array}{l}\text { Human circadian locomotor output } \\
\text { cycles kaput gene }\end{array}$ \\
\hline$B M A L 1$ & $=$ & $\begin{array}{l}\text { Human aryl hydrocarbon receptor } \\
\text { nuclear translocator-like protein } 1 \text {, } \\
\text { brain and muscle gene }\end{array}$ \\
\hline PERl-3 & $=$ & Human period genes $1-3$ \\
\hline$C R Y 1-2$ & $=$ & Human cryptochrome genes $1-2$ \\
\hline$T I M$ & $=$ & Human timeless gene \\
\hline SFA & $=$ & Spindle frequency activity \\
\hline $\mathrm{SCN}$ & $=$ & Suprachiasmatic nuclei \\
\hline PET & $=$ & Positron emission tomography \\
\hline VLPO & $=$ & Ventro-lateral preoptic area \\
\hline GABA & $=$ & $\gamma$-Amino-butyric acid \\
\hline $\mathrm{LC}$ & $=$ & Locus coeruleus \\
\hline DRN & $=$ & Dorsal raphe nucleus \\
\hline $\mathrm{TMN}$ & $=$ & Tuberomammillary nucleus \\
\hline $\mathrm{LDT} / \mathrm{PPT}$ & $=$ & $\begin{array}{l}\text { Latero-dorsal/pedunculo-pontine } \\
\text { tegmental areas }\end{array}$ \\
\hline Dat & $=$ & Mouse dopamine transporter gene \\
\hline
\end{tabular}




\begin{tabular}{|c|c|}
\hline $5-\mathrm{HT}$ & $=5$-Hydroxy-tryptamine, serotonin \\
\hline SNP & $=$ Single nucleotide polymorphism \\
\hline UTR & $=$ Untranslated region \\
\hline RNA & $=$ Ribonucleic acid \\
\hline Perl-3 & $=$ Mouse period genes 1-3 \\
\hline DSPS & $=$ Delayed sleep phase syndrome \\
\hline FASPS & $\begin{array}{l}=\text { Familial advanced sleep phase } \\
\text { syndrome }\end{array}$ \\
\hline CKI $\delta$ & $=$ Human casein kinase I delta protein \\
\hline VNTR & $=$ Variable-number-tandem-repeats \\
\hline$A D A, \mathrm{ADA}$ & $=\underset{\text { protein }}{\text { Human adenosine deaminase gene and }}$ \\
\hline QTL & $=$ Quantitative trait locus \\
\hline Ada & $=$ Mouse adenosine deaminase gene \\
\hline COMT, COMT $=$ & $\begin{aligned}= & \text { Human catechol-O-methyltransferase } \\
& \text { gene and protein }\end{aligned}$ \\
\hline$M A O-A, \mathrm{MAO}-\mathrm{A}=$ & $\begin{array}{l}=\text { Human monoamine oxidase type } \mathrm{A} \\
\text { gene and protein }\end{array}$ \\
\hline MSLT & $=$ Multiple sleep latency test \\
\hline SLC6A4 & $=$ Human serotonin transporter gene \\
\hline 5-HIAA & $=5$-Hydroxy-indolacetic acid \\
\hline $5-\mathrm{HTT}$ & $=$ Serotonin transporter \\
\hline CSNK2A2 & $=$ Human casein kinase II alpha- 2 gene \\
\hline PROK2 & $=$ Human prokineticin 2 gene \\
\hline NPSR1 & $=$ Human neuropeptide $\mathrm{S}$ receptor 1 gene \\
\hline$P D E 4 D$ & $=$ Human phosphodiesterase $4 \mathrm{D}$ gene \\
\hline$A D O R A 2 A$ & $=$ Human adenosine $\mathrm{A}_{2 \mathrm{~A}}$ receptor gene \\
\hline
\end{tabular}

\section{REFERENCES}

[1] Borbély AA. A two process model of sleep regulation. Hum Neurobiol 1982; 1: 195-204.

[2] Dijk D-J, Czeisler CA. Contribution of the circadian pacemaker and the sleep homeostat to sleep propensity, sleep structure, electroencephalographic slow waves, and sleep spindle activity in humans. J Neurosci 1995; 15: 3526-38.

[3] Borbély AA, Achermann P. In: Kryger MH, Roth T, Dement WC Eds, Principles and Practice of Sleep Medicine. Philadelphia, PA: Elsevier Saunders 2005; 405-17.

[4] Dijk DJ, von Schantz M. Timing and consolidation of human sleep, wakefulness, and performance by a symphony of oscillators. J Biol Rhythms 2005; 20: 279-90.

[5] Schmidt C, Collette F, Cajochen C, Peigneux P. A time to think: Circadian rhythms in human cognition. Cogn Neuropsych 2007; 24: 755-89.

[6] Lim JL, Dinges DF. Sleep deprivation and vigilant attention. Ann N Y Acad Sci 2008; 1129: 305-22.

[7] Wirz-Justice A, Van den Hoofdakker RH. Sleep deprivation in depression: what do we know, where do we go? Biol Psychiatry 1999; 46: 445-53.

[8] Barnard AR, Nolan PM. When clocks go bad: Neurobehavioural consequences of disrupted circadian timing. PLoS Genetics 2008; 4:-.

[9] Horne JA, Östberg O. A self-assessment questionnaire to determine morningness-eveningness in human circadian rhythms. Int J Chronobiol 1976; 4: 97-110.
[10] Torsvall L, Akerstedt T. A diurnal type scale. Scand J Work Environ Health 1980; 6: 283-90.

[11] Mishima K, Tozawa T, Satoh K, Saitoh H, Mishima Y. The $3111 \mathrm{~T} / \mathrm{C}$ polymorphism of hClock is associated with evening preference and delayed sleep timing in a Japanese population sample. Am J Med Genet B Neuropsychiatr Genet 2005; 133B: 101-4.

[12] Koskenvuo M, Hublin C, Partinen M, Heikkila K, Kaprio J. Heritability of diurnal type: a nationwide study of 8753 adult twin pairs. J Sleep Res 2007; 16: 156-62.

[13] Aeschbach D, Sher L, Postolache TT, Matthews JR, Jackson MA, Wehr TA. A longer biological night in long sleepers than in short sleepers. J Clin Endocrinol Metab 2003; 88: 26-30.

[14] Aeschbach D, Cajochen C, Landolt HP, Borbély AA. Homeostatic sleep regulation in habitual short sleepers and long sleepers. Am J Physiol 1996; 270: R41-53.

[15] Aeschbach D, Postolache TT, Sher L, Matthews JR, Jackson MA, Wehr TA. Evidence from the waking electroencephalogram that short sleepers live under higher homeostatic sleep pressure than long sleepers. Neuroscience 2001; 102: 493-502.

[16] Rétey JV, Adam M, Khatami R, Luhmann UFO, Jung HH, Berger $\mathrm{W}$, et al. A genetic variation in the adenosine $\mathrm{A}_{2 \mathrm{~A}}$ receptor gene (ADORA2A) contributes to individual sensitivity to caffeine effects on sleep. Clin Pharmacol Ther 2007; 81: 692-8.

[17] Gedda L, Brenci G. Sleep and dream characteristics in twins. Acta Genet Med Gemellol 1979; 28(3): 237-9.

[18] Partinen M, Kaprio J, Koskenvuo M, Putkonen P, Langinvainio H. Genetic and environmental determination of human sleep. Sleep 1983; 6: 179-85.

[19] Heath AC, Kendler KS, Eaves LJ, Martin NG. Evidence for genetic influences on sleep disturbance and sleep pattern in twins. Sleep 1990; 13: 318-35.

[20] Rechtschaffen A, Kales A. A manual of standardized terminology, techniques and scoring system for sleep stages of human subjects, National Institutes of Health: Bethesda, Maryland; 1968.

[21] Merica H, Gaillard JM. Statistical description and evaluation of the interrelationships of standard sleep variables for normal subjects. Sleep 1985; 8: 261-73

[22] Tan X, Campbell IG, Feinberg I. Internight reliability and benchmark values for computer analyses of non-rapid eye movement (NREM) and REM EEG in normal young adult and elderly subjects. Clin Neurophysiol 2001; 112: 1540-52.

[23] Buckelmüller J, Landolt HP, Stassen HH, Achermann P. Trait-like individual differences in the human sleep electroencephalogram. Neuroscience 2006; 138: 351-6.

[24] Tucker AM, Dinges DF, Van Dongen HPA. Trait interindividual differences in the sleep physiology of healthy young adults. J Sleep Res 2007; 16: 170-80.

[25] Zung WW, Wilson WP. Sleep and dream patterns in twins. Markov analysis of a genetic trait. Recent Adv Biol Psychiatry 1966; 9: 119-30.

[26] Webb WB, Campbell SS. Relationships in Sleep Characteristics of Identical and Fraternal-Twins. Arch Gen Psychiatry 1983; 40: 1093-5.

[27] Chouvet G, Blois R, Debilly G, Jouvet M. La structure d'occurrence des mouvements oculaires rapides du sommeil paradoxal est similaire chez les jumeaux homozygotes. C R Acad Sc Paris III 1983; 296: 1063-8.

[28] Linkowski P. EEG sleep patterns in twins. J Sleep Res 1999; 8 Suppl 1: 11-3.

[29] Borbély AA, Baumann F, Brandeis D, Strauch I, Lehmann D. Sleep deprivation: effect on sleep stages and EEG power density in man. Electroencephalogr Clin Neurophysiol 1981; 51: 483-93.

[30] Geering BA, Achermann P, Eggimann F, Borbély AA. Periodamplitude analysis and power spectral analysis: a comparison based on all-night sleep EEG recordings. J Sleep Res 1993; 2: 121-9.

[31] Ambrosius U, Lietzenmaier S, Wehrle R, Wichniak A, Kalus S, Winkelmann $\mathrm{J}$, et al. Heritability of sleep electroencephalogram. Biol Psychiatry 2008; 64: 344-8.

[32] De Gennaro L, Marzano C, Fratello F, Moroni F, Pellicciari MC, Ferlazzo F, et al. The EEG fingerprint of sleep is genetically determined: a twin study. Ann Neurol 2008; 64(4): 455-60.

[33] Lennox WG, Gibbs EL, Gibbs FA. The brain-wave pattern, an hereditary trait - evidence from 74 normal pairs of twins. J Heredity 1945; 36: 233-43. 
[34] Vogel F. Ueber die Erblichkeit des normalen Elektroenzephalogramms: Vergleichende Untersuchungen an ein- und zweieiigen Zwillingen, Georg Thieme Verlag: Stuttgart; 1958.

[35] Juel-Nielson N, Harvald B. The electroencephalogram in uniovular twins brought up apart. Acta Genet 1958; 8: 57-64.

[36] Stassen HH, Bomben G, Propping P. Genetic aspects of the EEG: an investigation into the within-pair similarity of monozygotic and dizygotic twins with a new method of analysis. Electroencephalogr clin Neurophysiol 1987; 66: 489-501.

[37] van Beijsterveldt CE, Molenaar PC, de Geus EJ, Boomsma DI. Heritability of human brain functioning as assessed by electroencephalography. Am J Hum Genet 1996; 58: 562-73.

[38] Borbély AA. In: Koukkou M, Lehmann D, Angst J, Eds., Functional states of the brain: their determinants. Amsterdam, Elsevier 1980; 151-61.

[39] Tobler I. In: Kryger MH, Roth T, Dement WC, Eds., Principles and Practice of Sleep Medicine. Philadelphia, PA, Elsevier Saunders 2005; 77-90.

[40] Dijk DJ, Beersma DGM, Daan S. EEG power density during nap sleep: reflection of an hourglass measuring the duration of prior wakefulness. J Biol Rhythms 1987; 2: 207-19.

[41] Rétey JV, Adam M, Gottselig JM, Khatami R, Dürr R, Achermann $\mathrm{P}$, et al. Adenosinergic mechanisms contribute to individual differences in sleep-deprivation induced changes in neurobehavioral function and brain rhythmic activity. J Neurosci 2006; 26: 10472-9.

[42] Knoblauch V, Martens WL, Wirz-Justice A, Cajochen C. Human sleep spindle characteristics after sleep deprivation. Clin Neurophysiol 2003; 114: 2258-67.

[43] Torsvall L, Akerstedt T. Sleepiness on the job: Continuously measured EEG changes in train drivers. Electroencephalogr clin Neurophysiol 1987; 66: 502-11.

[44] Cajochen C, Brunner DP, Kräuchi K, Graw P, Wirz-Justice A. Power density in theta/alpha frequencies of the waking EEG progressively increases during sustained wakefulness. Sleep 1995; 18: 890-4.

[45] Aeschbach D, Matthews JR, Postolache TT, Jackson MA, Giesen HA, Wehr TA. Dynamics of the human EEG during prolonged wakefulness: evidence for frequency-specific circadian and homeostatic influences. Neurosci Lett 1997; 239: 121-4.

[46] Finelli LA, Baumann H, Borbély AA, Achermann P. Dual electroencephalogram markers of human sleep homeostasis: correlation between theta activity in waking and slow-wave activity in sleep. Neuroscience 2000; 101: 523-9.

[47] Finelli LA, Acherman P, Borbely AA. Individual 'fingerprints' in human sleep EEG topography. Neuropsychopharmacology 2001; 25(Suppl 5): S57-62.

[48] De Gennaro L, Ferrara M, Vecchio F, Curcio G, Bertini M. An electroencephalographic fingerprint of human sleep. NeuroImage 2005; 26: 114-22.

[49] Van Dongen HP, Maislin G, Mullington JM, Dinges DF. The cumulative cost of additional wakefulness: dose-response effects on neurobehavioral functions and sleep physiology from chronic sleep restriction and total sleep deprivation. Sleep 2003; 26: 117-26.

[50] Leproult R, Colecchia EF, Berardi AM, Stickgold R, Kosslyn SM, Van Cauter E. Individual differences in subjective and objective alertness during sleep deprivation are stable and unrelated. Am J Physiol 2003; 284: R280-90.

[51] Frey DJ, Badia P, Wright KP. Inter- and intra-individual variability in performance near the circadian nadir during sleep deprivation. J Sleep Res 2004; 13: 305-15.

[52] Galliaudi E, Taillard J, Sagaspei P, Valtati C, Bioulac B, Philip P. Sharp and sleepy: evidence for dissociation between sleep pressure and nocturnal performance. J Sleep Res 2008; 17: 11-5.

[53] Van Dongen HPA, Baynard MD, Maislin G, Dinges DF. Systematic interindividual differences in neurobehavioral impairment from sleep loss: Evidence of trait-like differential vulnerability. Sleep 2004; 27: 423-33.

[54] Van Dongen HP, Vitellaro KM, Dinges DF. Individual differences in adult human sleep and wakefulness: Leitmotiv for a research agenda. Sleep 2005; 28: 479-96.

[55] Shaw PJ, Franken P. Perchance to dream: Solving the mystery of sleep through genetic analysis. J Neurobiol 2003; 54: 179-202.

[56] Tafti M, Maret S, Dauvilliers Y. Genes for normal sleep and sleep disorders. Ann Med 2005; 37: 580-9.

[57] Wisor JP, Kilduff TS. Molecular genetic advances in sleep research and their relevance to sleep medicine. Sleep 2005; 28: 357-67.
[58] Tafti M, Franken P. Invited review: Genetic dissection of sleep. J Appl Physiol 2002; 92: 1339-47.

[59] Franken P, Tafti M. Genetics of sleep and sleep disorders. Front Biosci 2003; 8: e381-97.

[60] Steriade M. The corticothalamic system in sleep. Front Biosci 2003; 8: 878-99.

[61] Jones BE. From waking to sleeping: neuronal and chemical substrates. Trends Pharm Sci 2005; 26: 578-86.

[62] Saper CB, Scammell TE, Lu J. Hypothalamic regulation of sleep and circadian rhythms. Nature 2005; 437: 1257-63.

[63] Stenberg D. Neuroanatomy and neurochemistry of sleep. Cell Mol Life Sci 2007; 64: 1187-204.

[64] Porkka-Heiskanen T, Strecker RE, Thakkar M, Bjorkum AA, Greene RW, McCarley RW. Adenosine: a mediator of the sleepinducing effects of prolonged wakefulness. Science 1997; 276: 1265-8.

[65] Porkka-Heiskanen T, Strecker RE, McCarley RW. Brain sitespecificity of extracellular adenosine concentration changes during sleep deprivation and spontaneous sleep: an in vivo microdialysis study. Neuroscience 2000; 99: 507-17.

[66] McCarley RW. Neurobiology of REM and NREM sleep. Sleep Med 2007; 8: 302-30.

[67] Siegel J, Radulovacki M, Heller HC, Alam MN, Szymusiak R, McGinty D, et al. Commentaries on: Blanco-Centurion C, Xu M, Murillo-Rodriguez E et al. Adenosine and sleep homeostasis in the basal forebrain. J Neurosci 26(31): 8092-8100, August 2, 2006. Sleep 2006; 29: 1381-9.

[68] Elmenhorst D, Meyer PT, Winz OH, Matusch A, Ermert J, Coenen $\mathrm{HH}$, et al. Sleep deprivation increases $\mathrm{A}(1)$ adenosine receptor binding in the human brain: A positron emission tomography study. J Neurosci 2007; 27: 2410-5.

[69] Koyama Y, Hayaishi O. Firing of neurons in the preoptic/anterior hypothalamic areas in rat: its possible involvement in slow wave sleep and paradoxical sleep. Neurosci Res 1994; 19: 31-8.

[70] Szymusiak R, Alam N, Steininger TL, McGinty D. Sleep-waking discharge patterns of ventrolateral preoptic/anterior hypothalamic neurons in rats. Brain Res 1998; 803: 178-88.

[71] Sherin JE, Shiromani PJ, McCarley RW, Saper CB. Activation of ventrolateral preoptic neurons during sleep. Science 1996; 271: 216-9.

[72] Nofzinger EA, Buysse DJ, Miewald JM, Meltzer CC, Price JC, Sembrat RC, et al. Human regional cerebral glucose metabolism during non-rapid eye movement sleep in relation to waking. Brain 2002; 125: 1105-15.

[73] Gaus SE, Strecker RE, Tate BA, Parker RA, Saper CB. Ventrolateral preoptic nucleus contains sleep-active, galaninergic neurons in multiple mammalian species. Neuroscience 2002; 115: 285-94.

[74] Gallopin T, Fort P, Eggermann E, Cauli B, Luppi PH, Rossier J, et al. Identification of sleep-promoting neurons in vitro. Nature 2000; 404: 992-5.

[75] Sherin JE, Elmquist JK, Torrealba F, Saper CB. Innervation of histaminergic tuberomammillary neurons by GABAergic and galaninergic neurons in the ventrolateral preoptic nucleus of the rat. J Neurosci 1998; 18: 4705-21.

[76] Lu J, Greco MA, Shiromani P, Saper CB. Effect of lesions of the ventrolateral preoptic nucleus on NREM and REM sleep. J Neurosci 2000; 20: 3830-42.

[77] Steininger TL, Gong H, McGinty D, Szymusiak R. Subregional organization of preoptic area/anterior hypothalamic projections to arousal-related monoaminergic cell groups. J Comp Neurol 2001; 429: 638-53.

[78] Lu J, Bjorkum AA, Xu M, Gaus SE, Shiromani PJ, Saper CB. Selective activation of the extended ventrolateral preoptic nucleus during rapid eye movement sleep. J Neurosci 2002; 22: 4568-76.

[79] Chou TC, Bjorkum AA, Gaus SE, Lu J, Scammell TE, Saper CB. Afferents to the ventrolateral preoptic nucleus. J Neurosci 2002; 22: 977-90.

[80] Morairty S, Rainnie D, McCarley R, Greene R. Disinhibition of ventrolateral preoptic area sleep-active neurons by adenosine: a new mechanism for sleep promotion. Neuroscience 2004; 123: 451-7.

[81] Gallopin T, Luppi PH, Cauli B, Urade Y, Rossier J, Hayaishi O, et al. The endogenous somnogen adenosine excites a subset of sleep-promoting neurons via A2A receptors in the ventrolateral preoptic nucleus. Neuroscience 2005; 134: 1377-90. 
[82] McCoy JG, Tartar JL, Bebis AC, Ward CP, McKenna JT, Baxter $\mathrm{MG}$, et al. Experimental sleep fragmentation impairs attentional set-shifting in rats. Sleep 2007; 30: 52-60.

[83] Moruzzi G, Magoun HW. Brain stem and EEG activation. Electroencephalogr clin Neurophysiol 1949; 1: 455-73.

[84] Berridge CW, Waterhouse BD. The locus coeruleus-noradrenergic system: modulation of behavioral state and state-dependent cognitive processes. Brain Res Rev 2003; 42: 33-84.

[85] Aston-Jones G, Bloom FE. Activity of norepinephrine-containing locus coeruleus neurons in behaving rats anticipates fluctuations in the sleep-waking cycle. J Neurosci 1981; 1: 876-86.

[86] Cirelli C, Huber R, Gopalakrishnan A, Southard TL, Tononi G. Locus ceruleus control of slow-wave homeostasis. J Neurosci 2005; 25: 4503-11.

[87] Arnulf I. Sleep and wakefulness disturbances in Parkinson's disease. J Neural Transm Suppl 2006; 70: 357-60.

[88] Lu J, Jhou TC, Saper CB. Identification of wake-active dopaminergic neurons in the ventral periaqueductal gray matter. J Neurosci 2006; 26: 193-202.

[89] Rang HP, Dale MM, Ritter JM, Flower R. Rang \& Dale's Pharmacology, Churchill Livingstone; 2007.

[90] Wisor JP, Nishino S, Sora I, Uhl GH, Mignot E, Edgar DM. Dopaminergic role in stimulant-induced wakefulness. J Neurosci 2001; 21: 1787-94.

[91] Jouvet M. The role of monoamines and acetylcholine-containing neurons in the regulation of the sleep-waking cycle. Ergeb Physiol 1972; 64: 166-307.

[92] Ursin R. Serotonin and sleep. Sleep Med Rev 2002; 6: 55-69.

[93] McGinty DJ, Harper RM. Dorsal raphe neurons: depression of firing during sleep in cats. Brain Res 1976; 101: 569-75.

[94] Trulson ME, Jacobs BL. Raphe unit activity in freely moving cats: correlation with level of behavioral arousal. Brain Res 1979; 163: 135-50.

[95] Penalva RG, Lancel M, Flachskamm C, Reul JM, Holsboer F, Linthorst AC. Effect of sleep and sleep deprivation on serotonergic neurotransmission in the hippocampus: a combined in vivo microdialysis/EEG study in rats. Eur J Neurosci 2003; 17: 1896-906.

[96] Portas CM, McCarley RW. Behavioral state-related changes of extracellular serotonin concentration in the dorsal raphe nucleus: a microdialysis study in the freely moving cat. Brain Res 1994; 648: 306-12.

[97] Zeitzer JM, Maidment NT, Behnke EJ, Ackerson LC, Fried I, Engel J, Jr., et al. Ultradian sleep-cycle variation of serotonin in the human lateral ventricle. Neurology 2002; 59: 1272-4.

[98] Beelman CA, Parker R. Degradation of messenger-RNA in Eukaryotes. Cell 1995; 81: 179-83.

[99] Katzenberg D, Young T, Finn L, Lin L, King DP, Takahashi JS, et al. A CLOCK polymorphism associated with human diurnal preference. Sleep 1998; 21: 569-76.

[100] Robilliard DL, Archer SN, Arendt J, Lockley SW, Hack LM, English $\mathrm{J}$, et al. The 3111 Clock gene polymorphism is not associated with sleep and circadian rhythmicity in phenotypically characterized human subjects. J Sleep Res 2002; 11: 305-12.

[101] Pedrazzoli M, Louzada FM, Pereira DS, Benedito-Silva AA, Lopez $\mathrm{AR}$, Martynhak BJ, et al. Clock polymorphisms and circadian rhythms phenotypes in a sample of the Brazilian population. Chronobiol Int 2007; 24: 1-8.

[102] Serretti A, Benedetti F, Mandelli L, Lorenzi C, Pirovano A, Colombo C, et al. Genetic dissection of psychopathological symptoms: Insomnia in mood disorders and CLOCK gene polymorphism. Am J Med Genet B Neuropsychiatr Genet 2003; 121B: 358.

[103] Serretti A, Cusin C, Benedetti F, Mandelli L, Pirovano A, Zanardi $\mathrm{R}$, et al. Insomnia improvement during antidepressant treatment and CLOCK gene polymorphism. Am J Med Genet B Neuropsychiatr Genet 2005; 137B: 36-9.

[104] Benedetti F, Dallaspezia S, Fulgosi MC, Lorenzi C, Serretti A, Barbini B, et al. Actimetric evidence that CLOCK 3111 T/C SNP influences sleep and activity patterns in patients affected by bipolar depression. Am J Med Genet B Neuropsychiatr Genet 2007; 144B: 631-5.

[105] Bae K, Jin XW, Maywood ES, Hastings MH, Reppert SM, Weaver DR. Differential functions of mPer1, mPer2, and mPer3 in the SCN circadian clock. Neuron 2001; 30: 525-36.
[106] Carpen JD, von Schantz M, Smits M, Skene DJ, Archer SN. A silent polymorphism in the PER1 gene associates with extreme diurnal preference in humans. J Hum Genet 2006; 51: 1122-5.

[107] Katzenberg D, Young T, Lin L, Finn L, Mignot E. A human period gene (HPER1) polymorphism is not associated with diurnal preference in normal adults. Psychiatr Genet 1999; 9: 107-9.

[108] Toh KL, Jones CR, He Y, Eide EJ, Hinz WA, Virshup DM, et al. An hPer2 phosphorylation site mutation in familiar advanced sleep phase syndrome. Science 2001; 291: 1040-3.

[109] Xu Y, Padiath QS, Shapiro RE, Jones CR, Wu SC, Saigoh N, et al. Functional consequences of a CKI delta mutation causing familial advanced sleep phase syndrome. Nature 2005; 434: 640-4.

[110] Xu Y, Toh KL, Jones CR, Shin JY, Fu YH, Ptacek LJ. Modeling of a human circadian mutation yields insights into clock regulation by PER2. Cell 2007; 128: 59-70.

[111] Carpen JD, Archer SN, Skene DJ, Smits M, von Schantz M. A single-nucleotide polymorphism in the 5 '-untranslated region of the hPER2 gene is associated with diurnal preference. J Sleep Res 2005; $14: 293-7$.

[112] Archer SN, Robilliard DL, Skene DJ, Smits M, Williams A, Arendt $\mathrm{J}$, et al. A length polymorphism in the circadian clock gene Per3 is linked to delayed sleep phase syndrome and extreme diurnal preference. Sleep 2003; 26: 413-5.

[113] Pereira DS, Tufik S, Louzada FM, Benedito-Silva AA, Lopez AR, Lemos NA, et al. Association of the length polymorphism delayed sleep-phase syndrome: Does in the human Per3 gene with the latitude have an influence upon it? Sleep 2005; 28: 29-32.

[114] Viola AU, Archer SN, James LM, Groeger JA, Lo JC, Skene DJ, et al. PER3 polymorphism predicts sleep structure and waking performance. Curr Biol 2007; 17: 613-8.

[115] Groeger JA, Viola AU, Lo JCY, von Schantz M, Archer SN, Dijk DJ. Early morning executive fuctioning during sleep deprivation is compromised by a PERIOD3 polymorphism. Sleep 2008; 31: 1159-67.

[116] Burnstock G. Physiology and pathophysiology of purinergic neurotransmission. Physiol Rev 2007; 87: 659-797.

[117] Hirschhorn R, Yang DR, Israni A. An Asp8Asn substitution results in the adenosine deaminase (ADA) genetic polymorphism (ADA 2 allozyme): occurrence on different chromosomal backgrounds and apparent intragenic crossover. Ann Hum Genet 1994; 58: 1-9.

[118] Persico AM, Militerni R, Bravaccio C, Schneider C, Melmed R, Trillo $\mathrm{S}$, et al. Adenosine deaminase alleles and autistic disorder: case-control and family-based association studies. Am J Med Genet 2000; 96: 784-90.

[119] Battistuzzi G, Iudicone P, Santolamazza P, Petrucci R. Activity of adenosine deaminase allelic forms in intact erythrocytes and in lymphocytes. Ann Hum Genet 1981; 45: 15-9.

[120] Bottini N, De Luca D, Saccucci P, Fiumara A, Elia M, Porfirio MC, et al. Autism: evidence of association with adenosine deaminase genetic polymorphism. Neurogenet 2001; 3: 111-3.

[121] Rétey JV, Adam M, Honegger E, Khatami R, Luhmann UFO, Jung $\mathrm{HH}$, et al. A functional genetic variation of adenosine deaminase affects the duration and intensity of deep sleep in humans. Proc Natl Acad Sci USA 2005; 102: 15676-81.

[122] Franken P, Chollet D, Tafti M. The homeostatic regulation of sleep need is under genetic control. J Neurosci 2001; 21: 2610-21.

[123] Radulovacki M, Virus RM, Djuricic-Nedelson M, Green RD. Hypnotic effects of deoxycorformycin in rats. Brain Res 1983; 271: 392-5.

[124] Okada T, Mochizuki T, Huang ZL, Eguchi N, Sugita Y, Urade Y, et al. Dominant localization of adenosine deaminase in leptomeninges and involvement of the enzyme in sleep. Biochem Biophys Res Comm 2003; 312: 29-34.

[125] Koch H, Craig I, Dahlitz M, Denney R, Parkes D. Analysis of the monoamine oxidase genes and the Norrie disease gene locus in narcolepsy. Lancet 1999; 353: 645-6.

[126] Dauvilliers Y, Neidhart E, Lecendreux M, Billiard M, Tafti M. MAO-A and COMT polymorphisms and gene effects in narcolepsy. Mol Psychiatry 2001; 6: 367-72.

[127] Lachman HM, Papolos DF, Saito T, Yu YM, Szumlanski CL, Weinshilboum RM. Human catechol-O-methyltransferase pharmacogenetics: Description of a functional polymorphism and its potential application to neuropsychiatric disorders. Pharmacogenetics 1996; 6: 243-50

[128] Chen JS, Lipska BK, Halim N, Ma QD, Matsumoto M, Melhem S, et al. Functional analysis of genetic variation in catechol-o- 
methyltransferase (COMT): Effects on mRNA, protein, and enzyme activity in postmortem human brain. Am J Hum Genet 2004; 75: 807-21.

[129] Akil M, Kolachana BS, Rothmond DA, Hyde TM, Weinberger DR, Kleinman JE. Catechol-O-methyltransferase genotype and dopamine regulation in the human brain. J Neurosci 2003; 23: 2008-13.

[130] Wieczorek S, Jagiello P, Arning L, Dahmen N, Epplen JT. Screening for candidate gene regions in narcolepsy using a microsatellite based approach and pooled DNA. J Mol Med 2004; 82: 696-705.

[131] Hu XZ, Rush AJ, Charney D, Wilson AF, Sorant AJM, Papanicolaou GJ, et al. Association between a functional serotonin transporter promoter polymorphism and citalopram treatment in adult outpatients with major depression. Arch Gen Psychiatry 2007; 64: 783-92.

[132] Lesch KP, Bengel D, Heils A, Sabol SZ, Greenberg BD, Petri S, et $a l$. Association of anxiety-related traits with a polymorphism in the serotonin transporter gene regulatory region. Science 1996; 274 : 1527-31.

[133] Little KY, McLaughlin DP, Zhang L, Livermore CS, Dalack GW, McFinton PR, et al. Cocaine, ethanol, and genotype effects on human midbrain serotonin transporter binding sites and mRNA levels. Am J Psychiatry 1998; 155: 207-13.

[134] David SP, Murthy NV, Rabiner EA, Munafo MR, Johnstone EC, Jacob R, et al. A functional genetic variation of the serotonin (5HT) transporter affects 5-HT1A receptor binding in humans. J Neurosci 2005; 25: 2586-90.

[135] Brummett BH, Krystal AD, Ashley-Koch A, Kuhn CM, Zuchner S, Siegler IC, et al. Sleep quality varies as a function of 5-HTTLPR genotype and stress. Psychosom Med 2007; 69: 621-4.

[136] Linn S, McClure T, Monaghan K, Blulun D, Watson K, Roth T, et al. Association of serotonin transporter (5HTT) gene polymorphism with amount of slow-wave sleep in human subjects. Sleep 2007; 30: A365.

[137] Benedetti F, Serretti A, Colombo C, Campori E, Barbini B, di Bella $\mathrm{D}$, et al. Influence of a functional polymorphism within the promoter of the serotonin transporter gene on the effects of total sleep deprivation in bipolar depression. Am J Psychiatry 1999; 156: 1450-2.

[138] Wisor JP, Wurts SW, Hall FS, Lesch KP, Murphy DL, Uhl GR, et al. Altered rapid eye movement sleep timing in serotonin transporter knockout mice. Neuroreport 2003; 14: 233-8.

[139] Boutrel B, Monaca C, Hen R, Hamon M, Adrien J. Involvement of 5-HT1A receptors in homeostatic and stress-induced adaptive regulations of paradoxical sleep: Studies in 5-HT1A knock-out mice. J Neuroscience 2002; 22: 4686-92.

[140] Landolt HP, Meier V, Burgess HJ, Finelli LA, Cattelin F, Achermann $\mathrm{P}$, et al. Serotonin-2 receptors and human sleep: Effect of a selective antagonist on EEG power spectra. Neuropsychopharmacology 1999; 21: 455-66.

[141] Wafford KA, Ebert B. Emerging anti-insomnia drugs: tackling sleeplessness and the quality of wake time. Nature Rev Drug Disc 2008; 7 : 530-40.

[142] Gottlieb DJ, O'Connor GT, Wilk JB. Genome-wide association of sleep and circadian phenotypes. BMC Med Genet 2007; 8(Suppl 1): S9.
[143] Johns MW. A New Method for Measuring Daytime Sleepiness the Epworth Sleepiness Scale. Sleep 1991; 14: 540-5.

[144] Landolt HP. Sleep homeostasis: A role for adenosine in humans? Biochem Pharmacol 2008; 75: 2070-9.

[145] Satoh S, Matsumura H, Hayaishi O. Involvement of adenosine A(2a) receptor in sleep promotion. Eur J Pharmacol 1998; 351: 155-62.

[146] Satoh S, Matsumura H, Koike N, Tokunaga Y, Maeda T, Hayaishi $\mathrm{O}$. Region-dependent difference in the sleep-promoting potency of an adenosine A(2A) receptor agonist. Eur J Neurosci 1999; 11: 1587-97.

[147] Scammell TE, Gerashchenko DY, Mochizuki T, McCarthy MT, Estabrooke IV, Sears CA, et al. An adenosine A2a agonist increases sleep and induces Fos in ventrolateral preoptic neurons. Neuroscience 2001; 107: 653-63.

[148] Methippara MM, Kumar S, Alam MN, Szymusiak R, McGinty D. Effects on sleep of microdialysis of adenosine $A(1)$ and A(2a) receptor analogs into the lateral preoptic area of rats. Am J Physiol 2005; 289: R1715-R23.

[149] Hayaishi O, Urade Y, Eguchi N, Huang Z-L. Genes for prostaglandin $\mathrm{D}$ synthase and receptor as well as adenosine $\mathrm{A}_{2 \mathrm{~A}}$ receptor are involved in the homeostatic regulation of NREM sleep. Arch Ital Biol 2004; 142: 533-9.

[150] Huang ZL, Qu WM, Eguchi N, Chen JF, Schwarzschild MA, Fredholm $\mathrm{BB}$, et al. Adenosine $\mathrm{A}_{2 \mathrm{~A}}$, but not $\mathrm{A}_{1}$, receptors mediate the arousal effect of caffeine. Nature Neurosci 2005; 8: 858-9.

[151] Alsene K, Deckert J, Sand P, de Wit H. Association between A(2a) receptor gene polymorphisms and caffeine-induced anxiety. Neuropsychopharmacology 2003; 28: 1694-702.

[152] Perlis ML, Merica H, Smith MT, Giles DE. Beta EEG activity and insomnia. Sleep Med Rev 2001; 5: 365-76.

[153] Chait LD. Factors Influencing the Subjective Response to Caffeine. Behav Pharmacol 1992; 3: 219-28

[154] Childs E, Hohoff C, Deckert J, Xu K, Badner J, de Wit H. Association between ADORA2A and DRD2 polymorphisms and caffeineinduced anxiety. Neuropsychopharmacology 2008; 33: in press.

[155] Cornelis MC, El-Sohemy A, Campos H. Genetic polymorphism of the adenosine $\mathrm{A}_{2 \mathrm{~A}}$ receptor is associated with habitual caffeine consumption. Am J Clin Nutr 2007; 86: 240-4.

[156] Dauvilliers Y, Neidhart E, Billiard M, Tafti M. Sexual dimorphism of the catechol-O-methyltransferase gene in narcolepsy is associated with response to modafinil. Pharmacogenomics J 2002; 2: 658 .

[157] Madras BK, Xie ZH, Lin ZC, Jassen A, Panas H, Lynch L, et al. Modafinil occupies dopamine and norepinephrine transporters in vivo and modulates the transporters and trace amine activity in vitro. J Pharmacol Exp Ther 2006; 319: 561-9.

[158] Mattay VS, Goldberg TE, Fera F, Hariri AR, Tessitore A, Egan MF, et al. Catechol O-methyltransferase val(158)-met genotype and individual variation in the brain response to amphetamine. Proc Natl Acad Sci USA 2003; 100: 6186-91. 